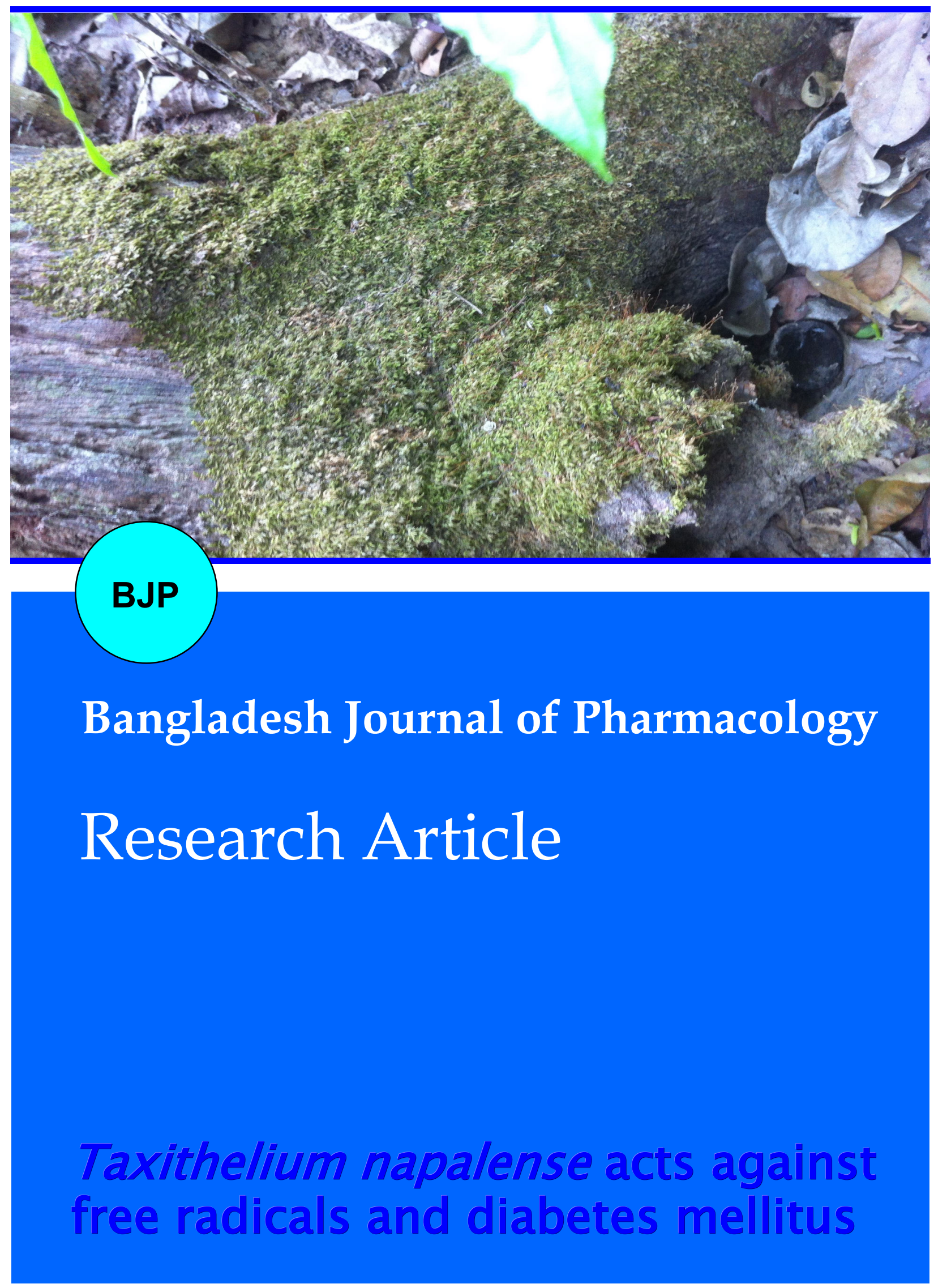


Abstracted/indexed in Academic Search Complete, Asia Journals Online, Bangladesh Journals Online, Biological Abstracts, BIOSIS Previews, CAB Abstracts, Current Abstracts, Directory of Open Access Journals, EMBASE/Excerpta Medica, Google Scholar, HINARI (WHO), International Pharmaceutical Abstracts, Open J-gate, Science Citation Index Expanded, SCOPUS and Social Sciences Citation Index;

ISSN: $1991-0088$

\title{
Taxithelium napalense acts against free radicals and diabetes mellitus
}

\author{
Vinay Bharadwaj Tatipamula, Kishore Naidu Killari, Alekhya Ketha and Girija Sastry Vedula
}

Andhra University College of Pharmaceutical Sciences, Andhra University, Visakhapatnam, Andhra Pradesh, India.

\begin{tabular}{|c|c|}
\hline Article Info & \\
\hline Received: & 3 March 2017 \\
\hline Accepted: & 24 April 2017 \\
\hline Available Online: & 16 June 2017 \\
\hline DOI: 10.3329/bjp.v & .31764 \\
\hline $\begin{array}{l}\text { Cite this article: } \\
\text { Tatipamula VB, K } \\
\text { Vedula GS. Taxith } \\
\text { against free radi } \\
\text { mellitus. Banglad } \\
\text { 2017; 12: 197-203. }\end{array}$ & $\begin{array}{l}\mathrm{KN} \text {, Ketha A, } \\
\text { napalense acts } \\
\text { and diabetes } \\
\mathrm{J} \text { Pharmacol. }\end{array}$ \\
\hline
\end{tabular}

\begin{abstract}
In this work, Taxithelium napalense ethanolic extract and its fractions were evaluated for the antidiabetic activity in rat based on phytochemical and free radical scavenging properties. The ethanolic extract, fraction IV and V significantly attenuated the blood glucose levels at 600, 200 and $200 \mathrm{mg} / \mathrm{kg}$ with 50.0, 33.5 and $42.0 \%$ inhibition respectively. The histopathological studies were manifesting the recuperation of damaged cells in liver and pancreas tissues. The outcomes of the present work affirm that the $T$. napalense has a potency to plummet the overproduction of free radicals and blood glucose levels in the diabetic-induced rat.
\end{abstract}

\section{Introduction}

Diabetes is a syndrome classified into a group of diseases evolved from several factors like oxidative stress conditions and defects in insulin action and secretion. Diabetes can damage the eyes, heart, kidneys and nerves (Nasri and Rafieian-Kopaei, 2014). Furthermore, earlier reports on diabetic patients strongly reveal the oxidative tissue damage due to high production of oxidants (Zitouni et al., 2005).

The demand on natural antidiabetic preparations/ products is gaining interest due to undesirable side effects, toxicity and high cost of synthetic drugs (oral hypoglycemic drugs) and insulin (Mohan et al., 2014; Emeka et al., 2015; Rehman et al., 2015; Ganesan et al., 2016).

Recently, mosses were scrutinized for biological evaluations because of their nutritional contents (Decker and Reski, 2007). For instance, Sphagnum palustre moss has renoprotective effects (Kang et al., 2016) and aromatase inhibitory activity (Eom et al., 2016). There were a few literatures available on mosses because of their distinct habitat from other plants and also less existence. In this outlook, the contemporary study is focused on to spot out the biological parameters of the uncommon moss, Taxithelium napalense (Schwager) Broth.

T. napalense, (Family Sematophyllaceae) an epiphytic moss, lives on twigs and branches of other plants in semi-evergreen forests located in the palaeotropical region (Ramsay et al., 2002). There is no phytochemical or biological evaluation report available till now on this moss. As this grown on stress conditions like low fresh water and sunlight, we are forethought to find out the chemical variants, anti-oxidant and antihyperglycemic potentialities of $T$. napalense.

\section{Materials and Methods}

\section{Moss material}

The entire moss, $T$. napalense was collected from Bhitarkanika Island $\left(20^{\circ} 72^{\prime} \mathrm{N}\right.$ latitude and $86^{\circ} 87^{\prime} \mathrm{E}$ Longitude) Orissa, India in March, 2016 on the barks of mangrove, Rhizophora species and was authenticated by Dr. Ankita Srivastava, National Botanical Research Institute (NBRI), Lucknow with an accession number 
(LWG-5/VB-Orissa-2016) had been deposited at the Bryophyte Herbarium, NBRI-Lucknow.

\section{Extraction and fractionation}

The air dried and powdered moss material was exhaustively extracted with ethanol and the extracted solvent was concentrated under reduced pressure gave a dried extract. Then the extract was used for column chromatography (Merck, \#230-400, 500 g) using step gradient elution of hexane/ethyl acetate (95:5) to ethyl acetate $(100 \%)$. The elution samples were divided into five fractions based on their thin layer chromatography observations (fraction I-V).

\section{Chemicals}

All the chemicals and reagents used for the present study were of analytical grade. Diagnostic kits were purchased from the Span Diagnostics Ltd (India). Alloxan monohydrate was from the Sigma Chemicals (USA) and glibenclamide from the Avantis Pharma Ltd.

\section{Phytochemical analysis}

The phytochemical analysis was carried out to ethanolic extract and fraction I-V of T. napalense using standard stratagems for identification of their chemical constituents (Trease and Evans, 2002).

\section{In vitro free radical scavenging activity}

The DPPH radical scavenging activity was deliberated as per method based on the measure of color absorbance of alcoholic DPPH solution (blue color) after addition of anti-oxidant solution (extract/compound). If anti-oxidants present in the test compound, a blue to yellow color change occurred due to reaction with DPPH (Rao et al., 2013).

Superoxide scavenging activity of the selected extract and its fractions were evaluated as per standard method-induction of superoxide free radical generation by riboflavin, the corresponding reduction by nitroblue tetrazolium and the absorption of light at $560 \mathrm{~nm}$ (Rao et al., 2013).

The percentage inhibition was measured by the following formula:

Percentage inhibition $=\frac{\mathrm{Ac}-\mathrm{Ae}}{\mathrm{Ac}} \times 100$

Where, Ac was the absorbance of the control, Ae was the absorbance of the extract/ascorbic acid

The 50\% inhibition concentration of extracts was identified by plotting the $X Y$ graph using the absorbance of the different concentrations of extract ( $X$-axis) against their percentage of inhibition (Y-axis).

\section{Animals}

Healthy albino rats of either sex weighing between 180$250 \mathrm{~g}$ aged 60-90 days were employed for the study.

\section{Acute toxicity studies}

The toxicity of ethanolic extract and fraction I-V were performed as per OECD guidelines. The albino rats of single sex were selected into two batches consisting of six animals each. The animals were subjected to acute toxicity study using each extract and fraction $\mathrm{I}-\mathrm{V}$ at a dose of 1,000 and $2,000 \mathrm{mg} / \mathrm{kg}$ orally in two batches at regular intervals of time i.e., 1, 2, 4, 8, 12 and 24 hours. During the time, the animals were under observation to different conditions like skin changes, morbidity, aggressiveness, oral secretions, sensitivity to sound and pain, respiratory movements and finally their mortality.

\section{Hypoglycemic activity}

Preparation of test samples: The ethanolic extract and fraction IV-V of the selected moss were deliquesced in $0.5 \%$ carboxymethylcellulose in distilled water and administrated to animals orally at $5 \mathrm{~mL} / \mathrm{kg}$. Glibenclamide $(50 \mathrm{mg} / \mathrm{kg})$ and $0.5 \%$ carboxymethylcellulose were administered to animals as standard and control respectively

Effects on normal and glucose-loaded rats: Fasting blood glucose levels of primarily divided eight groups' $(n=6)$ animals were deliberated and after 300 and $600 \mathrm{mg} / \mathrm{kg}$ body weight dose of ethanolic extract and 150 and $300 \mathrm{mg} / \mathrm{kg}$ body weight of fraction IV and $\mathrm{V}$ were administrated orally. Glibenclamide $(50 \mathrm{mg} / \mathrm{kg})$ was used as the standard drug and control group animals received $0.5 \%$ carboxymethylcellulose. Blood glucose levels were measured by tail vein puncture and glucometer (D'Orazio et al., 2005) at 30 and $60 \mathrm{~min}$. Then $2 \mathrm{~g} / \mathrm{kg}$ glucose was administered to animals orally and blood glucose levels were determined at $90^{\text {th }}$, $120^{\text {th }}, 240^{\text {th }}$ and $360^{\text {th }} \mathrm{min}$ for glucose tolerance test (Orhan et al., 2006).

Induction of diabetes: Alloxan monohydrate $(100 \mathrm{mg} /$ $\mathrm{kg}$ ) was administrated intraperitoneally for the induction of diabetes to rat after an overnight fasting (Monika and Aiman, 2012). Then, the animals were housed in a controlled facility and enabled to drink 5\% glucose solution to overwhelm the hypoglycemia. The diabetic state was confirmed by the quantification of fasting blood glucose concentration using glucometer with blood collected by tail vein puncture after 72 hours. Rats with blood glucose $\geq 200 \mathrm{mg} / \mathrm{dL}$ after 72 hours were perpetuated for succeeding four days and contemplated diabetic and used for further study.

Antidiabetic effect of ethanolic extract, fraction IV and $\mathrm{V}$ : The ethanolic extract of T. napalense (300 and 600 $\mathrm{mg} / \mathrm{kg}$ ) and best free radical scavenging fractions IV-V $200 \mathrm{mg} / \mathrm{kg}$ ) were studied. They were administrated orally twice a day for six days to diabetic animals disjoined into divergent groups ( $X$ groups; $n=6)$. The therapy to groups: Group I (control, administered with $0.5 \%$ carboxymethylcellulose), Group II to V (normal 
animals treated with taken concentration of extracts), Group VI (diabetic control, dosed with 0.5\% carboxymethylcellulose), Group VII [standard, diabetic animals medicated with glibenclamide $(50 \mathrm{mg} / \mathrm{kg}$ body weight)] and Groups VIII to XI (diabetic animals remedied with extract and fraction $I V-V$ as above mentioned concentrations).

\section{Collection of samples}

The blood glucose levels were scrutinized on fasting, day 1 , day 3, day 5 and day 7 . The effect of test samples on body weight of animals also monitored on these days. On day 7, blood samples were collected from the animals by puncturing of retro-orbital plexus under anesthesia (diethyl ether). These blood samples used for the estimation of plasma total cholesterol (TC), triglyceride (TG), high density lipoprotein (HDL), and low density lipoprotein (LDL) using Randox diagnostic kits (Assmann et al., 1983). The absorbance was determined and calculated using fully smart semi-automated analyzer and finally, animals were sacrificed. The kidneys, pancreas and liver were detached for measurement of lipid peroxidation (TBARS) and histopathological studies.

\section{Lipid peroxidation (TBARS) in tissues}

The isolated liver and kidneys were removed without delay and washed using $0.9 \% \mathrm{NaCl}$. The tissues were homogenized using homogenizer containing $4.5 \mathrm{~mL}$ of $0.25 \mathrm{M}$ sucrose. Then, cytosolic fraction was separated by centrifugation, first at $1000 \times \mathrm{g}$ for $10 \mathrm{~min}$ and then at $2000 \times \mathrm{g}$ for $30 \mathrm{~min}$ at $4^{\circ} \mathrm{C}$. The homogenate $(0.2 \mathrm{~mL})$ was mixed with $0.2 \mathrm{~mL}$ of $8.1 \%(\mathrm{w} / \mathrm{v})$ sodium dodecyl sulfate solution, $1.5 \mathrm{~mL}$ of $20 \%$ acetic acid solution of $\mathrm{pH} 3.5$ and $1.5 \mathrm{~mL}$ of $0.8 \%(\mathrm{w} / \mathrm{v})$ of thiobarbituric acid in a vial and the final volume was made up to $4.0 \mathrm{~mL}$ with distilled water. Then vials were heated in boiling water bath for $60 \mathrm{~min}$. Then, cooled the samples to room temperature and added equal volumes of tissue blank or test sample and $10 \%$ trichloroacetic acid were placed into a centrifuge tube. It was centrifuged at 1000 $\times \mathrm{g}$ for $10 \mathrm{~min}$ and the supernatant fraction was separated and measured the absorbance using spectrophotometer at $532 \mathrm{~nm}$ (Ohkawa et al., 1979).

\section{Histopathological studies}

The separated liver and pancreas were used for histopathological studies by preparing $2 \mathrm{~mm}$ sections using microtome. They were fixed in $10 \%$ formalin solution and stained with hematoxylen and eosin.

\section{Statistical analysis}

The values were given in mean \pm SEM. Statistical differences in extract, fractions and control groups were compared by two-way ANOVA and followed by Dunnet's test. The $p$ value $<0.05$ were considered statistically significant.

\section{Results}

The phytochemical analysis of the ethanolic extract and fraction I-V revealed different phytochemical constituents (Table I). The extract manifested the presence of steroids, saponins, carbohydrates, flavonoids, tannins, glycosides, phenolics but it gave negative results for alkaloids.

Fraction I divulged the existence of steroids, glycosides and phenolics. Fraction II had saponins and phenolics. Fraction III revealed the existence of flavonoids and phenolics. Fraction IV exhibited the presence of saponins, flavonoids and carbohydrates, whereas fraction $\mathrm{V}$ had saponins, flavonoids, carbohydrates, tannins and glycosides.

The crude extract exhibited good inhibition activity at high concentration i.e. $400 \mu \mathrm{g} / \mu \mathrm{L}$. It was comparable with the standard drug ascorbic acid. The fraction II-III had less percentage inhibition when compared with fraction IV, V and ethanolic extract (Table II). The preferable $\mathrm{IC}_{50}$ value on superoxide free radical was 255 $\mu \mathrm{g}$ for ethanolic extract and better $\mathrm{IC}_{50}$ value on $\mathrm{DPPH}$

\begin{tabular}{|c|c|c|c|c|c|c|}
\hline \multicolumn{7}{|c|}{ Table I } \\
\hline \multicolumn{7}{|c|}{ Phytochemical analysis of ethanolic extract and its fractions of T. napalense } \\
\hline \multirow[t]{2}{*}{ Phytochemical } & \multicolumn{6}{|c|}{ Extract/fraction of Taxithelium napalense } \\
\hline & Ethanolic & Fraction I & Fraction II & Fraction III & Fraction IV & Fraction V \\
\hline Steroids & Present & Present & - & - & - & - \\
\hline Saponins & Present & - & Present & - & Present & Present \\
\hline Alkaloids & - & - & - & - & - & - \\
\hline Carbohydrates & Present & - & - & - & Present & Present \\
\hline Flavonoids & Present & - & - & Present & Present & Present \\
\hline Tannins & Present & - & - & - & - & Present \\
\hline Glycosides & Present & Present & - & - & - & Present \\
\hline Phenolics & Present & Present & Present & Present & - & - \\
\hline
\end{tabular}




\begin{tabular}{|c|c|c|}
\hline \multicolumn{3}{|c|}{ Table II } \\
\hline \multicolumn{3}{|c|}{$\begin{array}{c}\mathrm{IC}_{50} \text { of } T \text {. napalense on supueroxide and DPPH free } \\
\text { radicals }\end{array}$} \\
\hline & \multicolumn{2}{|c|}{$\mathrm{IC}_{50}(\mu \mathrm{g})$ of free radical } \\
\hline & Superoxide & DPPH \\
\hline Ethanol extract & 255 & 312 \\
\hline Fraction I & & a \\
\hline Fraction II & a & a \\
\hline Fraction III & a & a \\
\hline Fraction IV & 353 & 322 \\
\hline Fraction $\mathrm{V}$ & 327 & 273 \\
\hline Ascorbic acid & 160 & 170 \\
\hline
\end{tabular}

aFractions did show the more than $50 \%$ inhibition on free radicals on tested free radicals

free radical was $273 \mu \mathrm{g}$ for fraction $\mathrm{V}$.

As per OECD guidelines, the toxicity studies of the ethanolic extract and its fractions showed no mortality in rats. They were in normal conditions at tested concentrations $(1,000$ and $2,000 \mathrm{mg} / \mathrm{kg})$. Hence, the tested extract was considered as safe and nontoxic. Further study was carried with 300 and $600 \mathrm{mg} / \mathrm{kg}$ body weight for antidiabetic activity.

The extract and fraction $\mathrm{V}$ significantly reduced the blood glucose levels in alloxan-diabetic rats at 600 and $200 \mathrm{mg} / \mathrm{kg}$ respectively on day 5 and day 7 (Table III). The ethanolic extract evinced the more percentage inhibition on glucose levels till day 7 of the study i.e. $50.0 \%$. The fraction V $(200 \mathrm{mg} / \mathrm{kg})$ manifested more percentage inhibition on the reduction of glucose levels when compared to ethanolic extract at $300 \mathrm{mg} / \mathrm{kg}$.

The body weight of the rats in distinct groups was also observed during the study. The untreated diabetic rat lost the body weight gradually when compared to the normal (Group II-V), ethanolic extract, fraction IV-V (Groups VIII-XI) animals. The animal groups dosed with ethanolic extract $(600 \mathrm{mg} / \mathrm{kg})$ gained more weight when compared to other groups.

The ethanolic extract and fractions IV-V had signifi-

Table III

\section{Effects of $T$. napalense on blood glucose level and \%inhibition in diabetic rat}

\begin{tabular}{|c|c|c|c|c|c|c|c|}
\hline \multirow[t]{2}{*}{ Name of the group } & \multicolumn{4}{|c|}{ Blood glucose concentration (mg/dL) } & \multicolumn{3}{|c|}{ (\% inhibition) } \\
\hline & Day 1 & Day 3 & Day 5 & Day 7 & Day 3 & Day 5 & Day 7 \\
\hline Control & $90 \pm 1.5$ & $93.3 \pm 1.4$ & $101 \pm 0.8$ & $92.9 \pm 0.3$ & - & - & - \\
\hline Diabetic control & $303.8 \pm 0.6$ & $306.3 \pm 0.2$ & $312 \pm 0.9$ & $314.5 \pm 0.4$ & - & - & - \\
\hline Glibenclamide (50 mg/kg) & $299.7 \pm 2.1$ & $239.5 \pm 0.4$ & $171.5 \pm 0.7$ & $100 \pm 0.9$ & 21.8 & 45.0 & 68.2 \\
\hline Ethanolic extract $(300 \mathrm{mg} / \mathrm{kg})$ & $282.7 \pm 1.3$ & $280 \pm 0.3$ & $231.8 \pm 0.6$ & $197.3 \pm 1.0$ & $8.6^{\mathrm{a}}$ & $25.7 \mathrm{a}$ & $37.3^{\mathrm{a}}$ \\
\hline Ethanolic extract $(600 \mathrm{mg} / \mathrm{kg})$ & $310 \pm 0.9$ & $255.8 \pm 0.6$ & $209.5 \pm 0.4$ & $157.3 \pm 0.2$ & $16.5^{\mathrm{a}}$ & $32.8^{\mathrm{b}}$ & $50.0^{a}$ \\
\hline Fraction IV (200 mg/kg) & $301 \pm 0.9$ & $276.8 \pm 0.6$ & $242.5 \pm 0.4$ & $209 \pm 0.3$ & $9.6^{\mathrm{ns}}$ & $22.3^{\mathrm{a}}$ & $33.5^{\mathrm{a}}$ \\
\hline Fraction V (200 mg/kg) & $303 \pm 0.3$ & $261.5 \pm 0.4$ & $227.3 \pm 0.7$ & $182.3 \pm 1.0$ & $14.6^{\mathrm{a}}$ & $27.1^{\mathrm{a}}$ & $42.0^{\mathrm{b}}$ \\
\hline
\end{tabular}

Data are mean \pm SEM; ap $<0.05 ;$ b $<<0.01$ and $c p<0.001$

\section{Table IV}

\section{Effects of T. napalense on TC, TG, HDL, LDL and TBARS contents in diabetic rat}

\begin{tabular}{|c|c|c|c|c|c|c|c|}
\hline Name of the parameter & Control & $\begin{array}{c}\text { Untreated } \\
\text { (Diabetic } \\
\text { control) }\end{array}$ & $\begin{array}{l}\text { Gliben- } \\
\text { clamide }\end{array}$ & $\begin{array}{c}\text { Ethanolic } \\
\text { ext (300 } \\
\mathrm{mg} / \mathrm{kg})\end{array}$ & $\begin{array}{c}\text { Ethanolic } \\
\text { ext }(600 \\
\mathrm{mg} / \mathrm{kg})\end{array}$ & $\begin{array}{c}\text { Fraction IV } \\
(200 \mathrm{mg} / \\
\mathrm{kg})\end{array}$ & $\begin{array}{c}\text { Fraction } \\
\text { V } \\
(200 \mathrm{mg} / \\
\mathrm{kg})\end{array}$ \\
\hline Total cholesterol (mg/dL) & $60 \pm 0.2$ & $150 \pm 0.1$ & $70 \pm 0.5$ & $140 \pm 1.1$ & $95 \pm 0.4$ & $130 \pm 1.5$ & $85 \pm 0.6$ \\
\hline Triglycerides (mg/dL) & $42 \pm 0.1$ & $175 \pm 0.4$ & $45 \pm 0.7$ & $100 \pm 0.3$ & $63 \pm 0.4$ & $85 \pm 0.8$ & $62 \pm 0.8$ \\
\hline $\mathrm{LDL}(\mathrm{mg} / \mathrm{dL})$ & $30 \pm 0.1$ & $138 \pm 0.2$ & $35 \pm 0.9$ & $105 \pm 0.5$ & $52 \pm 0.2$ & $74 \pm 0.2$ & $60 \pm 0.3$ \\
\hline $\mathrm{HDL}(\mathrm{mg} / \mathrm{dL})$ & $64 \pm 0.8$ & $35 \pm 0.5$ & $60 \pm 1.6$ & $42 \pm 0.7$ & $53 \pm 0.5$ & $48 \pm 0.4$ & $55 \pm 0.2$ \\
\hline $\begin{array}{l}\text { Kidney TBARS in } \mu \mathrm{mol} / \mathrm{g} \\
\pm \mathrm{SEM}(\% \text { change })\end{array}$ & $189.2 \pm 2.0$ & $\begin{array}{r}354 \pm 3.2 \\
(+87.1)\end{array}$ & $\begin{array}{r}204.3 \pm 2.0 \\
(-42.2)\end{array}$ & $\begin{array}{r}310.7 \pm 2.4 \\
(-12.3)^{\mathrm{a}}\end{array}$ & $\begin{array}{r}245.8 \pm 3.1 \\
(-30.5)^{\mathrm{a}}\end{array}$ & $\begin{array}{r}285 \pm 2.9 \\
(-19.4)^{\mathrm{b}}\end{array}$ & $\begin{array}{r}260.2 \pm 2.4 \\
\quad(-26.5)^{\mathrm{a}}\end{array}$ \\
\hline $\begin{array}{l}\text { Liver TBARS in } \mu \mathrm{mol} / \mathrm{g} \pm \\
\text { SEM ( } \% \text { change })\end{array}$ & $352.5 \pm 2.2$ & $\begin{array}{r}391.2 \pm 1.9 \\
(+11.0)\end{array}$ & $\begin{array}{r}357.7 \pm 2.3 \\
(-8.6)\end{array}$ & $\begin{array}{r}384.3 \pm 1.7 \\
(-1.7)^{\mathrm{a}}\end{array}$ & $\begin{array}{r}361.8 \pm 1.1 \\
(-7.5)^{\mathrm{b}}\end{array}$ & $\begin{array}{r}385.3 \pm 1.9 \\
(-1.5)^{\mathrm{a}}\end{array}$ & $\begin{array}{r}368.8 \pm 1.1 \\
(-5.7)^{\mathrm{b}}\end{array}$ \\
\hline
\end{tabular}

Data are mean \pm SEM; ap $<0.05 ;$ b $p<0.01$ and ${ }^{c} \mathrm{p}<0.001$ 
cantly stabilized the varied total cholesterol, triglyceride, HDL and LDL contents because of alloxandiabetes (Table IV).

TBARS content was proliferated in kidney and liver organs in diabetic rats. The ethanolic extract, fraction IV -V dosed groups significantly reduced the raised TBARS content with the percentage of change in levels varied from 1.5 to 30.5 (Table IV). Ethanolic extract at $600 \mathrm{mg} / \mathrm{kg}$ showed more reduction in TBARS content with $30.5 \%$. The change in the TBARS contents of tested extract and fractions were comparable with standard drug glibenclamide.

The liver and pancreatic tissues appeared normally in ethanol extract- and fraction V-treated group animals as control group animals (Figure 1). The hepatocytes showed normal structure. Gentle to modest portal inflammation were noted in lymphomononuclear and plasma cells of tested samples compared to normal rats, but it was less compared to the liver toxic animals. Sinusoids, hepatocytes and portal region appear ordinary in animals treated with glibenclamide compared to other groups. The pancreas structure of the diabetic rats was restored its structure by treating with $T$. napalense ethanolic extract and fraction $\mathrm{V}$ by reducing the swelling (increase in cell size), nucleomegaly (increase in the size of nuclei) and cytoplasmic vacuolations and eosinophils.

\section{Discussion}

The phytochemical analysis of $T$. napalense ethanolic extract and its fractions showed the presence of different phytochemical constituents but, the fractions showed dissimilarities in presence of phytoconstituents. The fractions IV and $\mathrm{V}$ chiefly contain bioactive compounds like flavanoids, tannins, glycosides and saponins. The extract and fractions were analyzed for their free radicals scavenging activity on superoxide and DPPH free radicals and they show signs of significant reduction in free radicals production. The ethanol extract and its main fractions IV and V were evaluated for their anti-diabetic activity and they showed good anti-diabetic activity on alloxan-induced diabetes.

As earlier mentioned, the demand for identification of new drugs from natural products gaining day by day (Mohan et al., 2014; Emeka et al., 2015; Rehman et al., 2015; Ganesan et al., 2016), current research was carried on moss, T. napalense and it is initial reports on phytochemical analysis, antioxidant capacity and antidiabetic capacity. There were some earlier reports on different biological activities on bryophytes including mosses (Laura et al., 2015; Vizma et al., 2012) but there was no reports on T. napalense.

The T. napalense exhibited significant reduction of free radicals and they do not have hyperglycemia or hypoglycemia in normal rats and manifested good antidiabetic activity. As diabetes mainly intensifies the oxidative stress and drops the antioxidants capacity of cells (Hays et al., 2008), likewise in alloxan-diabetes also foster equivalent effects, which was observed in the contemporary study i.e. the fluctuations in blood glucose levels, body weights, TC, TG, HDL, LDL contents in plasma and TBARS content in kidneys and liver. The weight loss was also observed in diabetic induced rats, this is due to excessive breakdown of the tissue proteins and lipids for the energy to maintain organs function. In addition, gentle to modest portal inflammation were noted in lymphomononuclear and plasma cells in the liver and swelling (increase in cell size), nucleomegaly (increase in size of nuclei) and cytoplasmic vacuolations and eosinophil sin pancreas was observed in the diabetic rats (Group II). The abnormalities of liver and pancreas were may be due to the over production of free radicals because of diabetic induction in the animals (Scofield et al., 1985; Pohl and Junge, 1997). But, after medication with the ethanolic extract and its fractions IV and $\mathrm{V}$, the animals started to procure their body weight and the fluctuations in lipid profile (TC, TG, HDL and LDL) were restored to their normal levels compared to diabetic animals (non-treated group). The liver and pancreatic tissues were appeared normal i.e. the hepatocytes are appear normal in normal structure, Sinusoids, hepatocytes and portal region appear ordinary and pancreas was with reduced swelling and nucleomegaly. The phytochemical analysis revealed presence of the tannins and glycosides and fraction $\mathrm{V}$ displayed better activity when compared to fraction IV, but less active than ethanolic extract. The anti-diabetic and anti-oxidant activities of T. napalense may be due to the presence of these constituents and more ever, flavanoids, tannins, saponins have been reported to exert different biological activities (Tapas et al., 2008; Elekofehinti et al., 2012; José et al., 2009). The variation in the activity of ethanolic extract and its fractions may be due to the indiviual constituents present in them, while the crude extract have more activity was may be due to their synergetic effect.

\section{Conclusion}

The discerned free radical scavenging and antidiabetic activities of $T$. napalense are due to the existence of major constituents like tannins, glycosides, flavonoids and saponins.

\section{Ethical Issue}

All the procedures followed as per OECD guidelines and regulations of Institutional Ethical Committee (Regd No. 516/01/A/CPCSEA). 


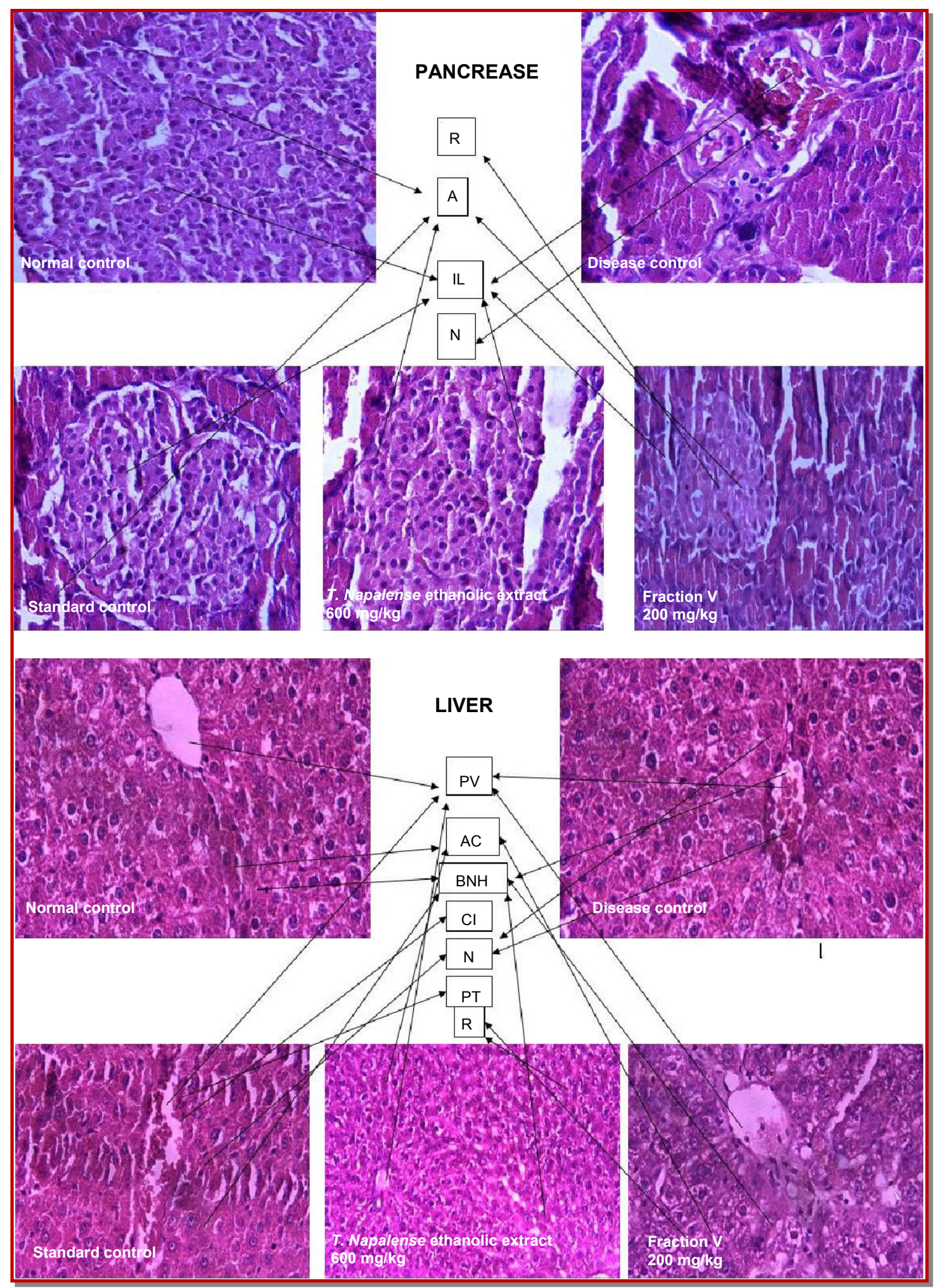

Figure 1: Effect of ethanolic extract and fraction V of Taxithelium napalense on histopathology of pancreas (upper two rows) and liver (lower two rows) after 7 days of study in normal- and alloxan-induced diabetic rats. A: Acnii; AC: Abundant cytoplasm; BNH: Binucleated hepatocytes; CI: Cellular Infiltration; IL: Islets of Langerhans; N: Necrosis; PT: Portal Tract; PV: Portal vein; R: Regeneration 


\section{Conflict of Interest}

All authors have completed the ICMJE uniform disclosure form and declare no support from any organization for the submitted work.

\section{Acknowledgement}

The authors are thankful to the Ministry of Earth Sciences, India for their financial support and expresses gratitude to Dr. Ankita Srivastava for determination, morphoanatomical of collected stressed moss specimens and preserving the study materials at Bryophyte Herbarium, CSIR-NBRI, LWG, India, to the authorities of AU College of Pharmaceutical Sciences, Andhra University for providing the necessary facilities to successfully complete the research.

\section{References}

Assmann G, Schriewer H, Schmitz G, Hägele EO. Quantification of high-density-lipoprotein cholesterol by precipitation with phosphotungstic acid/ $\mathrm{MgCl}_{2}$. Clin Chem. 1983; 29: 2026 -30 .

D'Orazio P, Burnett RW, Fogh-Andersen N, Jacobs E, Kuwa K, Külpmann WR, Larsson L, Lewnstam A, Maas AH, Mager G, Naskalski JW, Okorodudu AO. Approved IFCC recommendation on reporting results for blood glucose (abbreviated). Clin Chem. 2005; 51: 1573-76.

Decker EL, Reski R. Moss bioreactors producing improved biopharmaceuticals. Curr Opin Biotech. 2007; 18: 393-98.

Elekofehinti OO, Adanlawo IG, Komolafe K, Ejelonu OC. Saponins from Solanum anguivi fruits exhibit antioxidant potential in Wistar rats. Ann Biol Res. 2012; 3: 3212-17.

Emeka E, Oluwatoyin A, Adekunle O, Ignis I. Preliminary phytochemical screening and evaluation of hypoglycemic properties of the root extract of Uveria chamae. Bangladesh J Pharmacol. 2015; 10: 326-31.

Eom HJ, Park YJ, Kang HR, Kim HR, Bang IJ, Park HB, Chung $\mathrm{KH}$, Kim KH. Inhibitory effect of Sphagnum palustre extract and its bioactive compounds on aromatase activity. Bangladesh J Pharmacol. 2016; 11: 661-65.

Ganesan A, Mahesh A, Sundararaj J, Mani K, Ponnusamy P. Antihyperglycemic and anti-oxidant activity of various fraction of Parmotrema hababianumin streptozotocin-induced diabetic rat. Bangladesh J Pharmacol. 2016; 11: 935-39.

Hays NP, Galassetti PR, Coker RH. Prevention and treatment of type 2 diabetes: Current role of lifestyle, natural product, and pharmacological interventions. Pharmacol Ther. 2008; 118: 181-91.

José S, Riitta PP, Andreas D, Anna-Marja A, Fulgencio SC. Tannins: Current knowledge of food sources, intake, bioavailability and biological effects. Mol Nutr Food Res. 2009; 53 (Suppl 2): S310-S29.
Kang HR, Lee D, Eom HJ, Lee SR, Lee KR, Kang KS, Kim KH. Identification and mechanism of action of renoprotective constituents from peat moss Sphagnum palustre in cisplatininduced nephrotoxicity. J Funct Foods. 2016; 20: 358-68.

Laura K, Gunta S, Vizma N, Illia M, Ilva N, Diana D, Iveta S. Chemical composition analysis, antimicrobial activity and cytotoxicity screening of moss extracts (moss phytochemistry). Molecules. 2015; 20: 17221-43.

Mohan DS, Saraswathy M, Kurup MKG. Attenuation of hyperglycemia and hyperlipidemia in high calorie fed/ streptozotocin-treated rats by hydromethanolic extract of Padina tetrastromatica. Bangladesh J Pharmacol. 2014; 9: 37-42.

Monika M, Aiman U. Alloxan: An unpredictable drug for diabetes induction? Indian J Pharmacol. 2012; 44: 538-39.

Nasri H, Rafieian-Kopaei M. Protective effects of herbal antioxidants on diabetic kidney diseases. J Res Med Sci. 2014; 8283.

Ohkawa H, Oishi N, Yagi K. Assay for lipid peroxides in animal tissues by thiobartituric acid reaction. Anal Biochem. 1979; 95: 351-58.

Orhan N, Aslan M, Orhan DD, Ergun F, Yesilada E. In vivo assessment of antidiabetic and anti-oxidant activities of grapevine leaves (Vitis vinifera) in diabetic rats. J Ethnopharmacol. 2006; 108: 280-86.

Pohl R, Junge U. Primary sclerosing cholangitis with chronic pancreatitis. Dtsch Med Wochenschr. 1997; 122: 778-82.

Ramsay HP, Schofield WB, Tan BC. The genus Taxithelium (Bryopsida, Sematophyllaceae) in Australia. Aust Syst Bot. 2002; 15: 583-96.

Rao BG, Rao YV, Rao TM. Hepatoprotective and anti-oxidant capacity of Melochia corchorifolia extracts. Asian Pac J Trop Med. 2013; 6: 537-43.

Rehman MSU, Kamran SH, Ahmad M, Akhtar U. Anti-diabetic activity of crude Pistacia lentiscus in alloxan-induced diabetes in rats. Bangladesh J Pharmacol. 2015; 10: 543-47.

Scofield RF, Kosugi K, Schumann WC, Kumaran K, Landau BR. Quantitative estimation of the pathways followed in the conversion to glycogen of glucose administered to the fasted rat. J Biol Chem. 1985; 260: 8777-82.

Tapas AR, Sakarkar DM, Kakde RB. Flavonoids as nutraceuticals: A review. Trop J Pharm Res. 2008; 7: 1089-99.

Trease G, Evans SM. Pharmacognosy. 15th ed. Bailer Tindal, London, Elsevier Publisher, 2002, pp 23-67.

Vizma N, Ligita L, Zaiga P, Guntra K, Mara G, Indrikis M. Antibacterial activity of extracts from some Bryophytes. Adv Microbiol. 2012; 2: 345-53.

Zitouni K, Nourooz-Zadeh J, Harry D, Kerry SM, Betteridge DJ, Cappuccio FP, Earle KA. Race-specific differences in antioxidant enzyme activity in patients with type 2 diabetes: A potential association with the risk of developing nephropathy. Diabetes Care. 2005; 28: 1698-703.

\footnotetext{
Author Info

Vinay Bharadwaj Tatipamula (Principal contact)

i e-mail: vinaybharadwajt@gmail.com
} 


\section{Your feedback about this paper}

1. Number of times you have read this paper 0

2. Quality of paper Click

3. Your comments 